Donato, R. \& Lazerson, M. (2000). New Directions in American Educational History: Problems and Prospects. Educational Researcher, 29(8), 1-15. This work may be downloaded only. It may not be copied or used for any purpose other than scholarship. If you wish to make copies or use it for a non-scholarly purpose, please contact AERA directly.

\title{
New Directions in American Educational History: Problems and Prospects
}

\author{
RubÉn Donato Marvin Lazerson
}

This article, based on a Spencer Foundation sponsored conference on new directions in the history of education, examines the dilemma of audience and voice. It connects the "golden era" of American educational historiography to the education reforms of the 1960 s and 1970s, and then discusses recent developments in the areas of people of color, history and policy, higher education, and a genderbased history. It suggests ways history might be connected to current educational research issues.

Educational Researcher, Vol. 29, No. 8, pp. 4-15

There are so many things that surfaced for Chicanos in schools during the 1920s and 1930s that have not played themselves out. I tell my students to think carefully about this because we are studying ourselves today. (Gilbert Gonzalez, tape 2, pp. 37-38) $)^{1}$

n late March of 2000 approximately 40 U.S. historians of education gathered at a conference sponsored by the Spencer Foundation to discuss the condition of their field. The conference was part of the Foundation's broader effort to engage educational researchers in the areas of economics, political science, sociology, anthropology, and women's studies in similar examinations. At the conference educational historians had the rare opportunity to convene with their peers to discuss pressing issues, methodological concerns, and current research foci. They discussed issues of race/ethnicity, gender, higher education, policy, and so on. Within this context, participants reflected on the past and speculated on the future of the field.

The discussions raised a central challenge of being a historian of education: The dilemma of having to talk simultaneously to educational professionals and practitioners, educational researchers, and historians. This challenge is complicated by many historians' sense that the most interesting questions require an interdisciplinary approach, that they be comfortable in such diverse disciplines as anthropology, sociology, and economics, be conversant with cultural studies and postmodernist thought, and be capable of using qualitative and quantitative research methodologies. The difficulty of engaging in these cross-disciplinary activities is increased by the fact that most historians remain "soloists" in an environment where research is increasingly team-based across institutions and geographical boundaries.

Institutional ambiguities further compound the tensions. Most historians of education hold appointments in education schools, with an occasional appointment in a history department. Within education schools, historians commonly reside in departments of educational policy, curriculum and instruction, social foundations, administration, or higher education. Their students and colleagues frequently want them to provide insights and lessons for their contemporary concerns. Many historians are trained in programs with strong research traditions, yet teach in places without deep research commitments. When their work leads them into 20th-century issues, they face hurdles common among educational researchers, such as the veracity of interviews, that historians who work in earlier periods are less likely to confront. Social scientists place a high value on research design; educational historians often wonder what that means.

Institutional location, disciplinary training, professional spirations, and personal dispositions create conflicting obligations for the educational historian. As historians, we see ourselves adding to an existing body of historical knowledge. The questions we ask are rooted in the historiography of our discipline. In contrast, our connections to educational researchers and professionals lead us in another direction, to view the past in contemporary terms, finding historical questions in today's conflicts and framing the answers in ways that make sense to current-minded colleagues. In choosing one end of the spectrum, we risk neglect and rejection by the other, and are often seen either as antiquarians irrelevant to the burning educational issues of our times or as "presentists" with little appreciation of the uniqueness of the past.

Historians of education are most likely to be noticed when they take on a "hot-button" issue: What is the history of educational choice? What is the historic nature of gender discrimination? What was schooling like for communities of color in different parts of the nation? When and why did research come to dominate teaching in higher education's status hierarchy? These questions connect the past and the present. But, as most educational researchers understand, sophisticated analyses based on complex data frequently

RubÉn Donato is Associate Professor and Chair of Educational Foundations, Policy and Practice at The University of Colorado at Boulder, School of Education, Campus Box 249, Boulder, CO 80309. He specializes in history of American education and history of Mexican American education in the Southwest.

MARVIN LAZERson is Carruth Family Professor at the Graduate School of Education, University of Pennsylvania, 3700 Walnut Street, Philadelphia, PA 19104. His areas of specialization are history of American education and higher education administration. 
lead to complicated interpretations with ambiguous implications for policy and practice. As historians seek accuracy in their work, develop more sophisticated tools of empirical inquiry, and present complex interpretations of the past, they also complicate their ability to find clear lessons and to make the kind of assessments about the present that other educational researchers and policymakers and practitioners prefer. Further, given that most historians of education teach students who are committed to becoming educational professionals so as to improve educational quality, they are challenged to be relevant.

In practice, educational historians usually achieve a balance in speaking simultaneously about the past and about the present. They do so by emphasizing historical study as a way of thinking and understanding, and by writing about sweeping themes like education and the democratic state, while simultaneously building evidentiary blocks of historical data. They write scholarly articles, books, and op-ed pieces. The dilemma remains an ongoing challenge, however. As historian James Leloudis put it, educational history has "the potential to be a remarkably powerful tool for thinking critically about policy. Yet, we have a particularly hard time finding a voice at policy tables" (Leloudis, tape 2, pp. 2-3).

We begin this essay by considering the scholarship of the 1960 s and 1970s - the "golden era" of American educational history -in order to provide a context for understanding where the field has been and where it is heading. To outline an agenda for the future, we examine the literature on the educational histories of people of color, the relationship between historical research and educational policy, the revised histories of higher education, and the work on the significance of gender in education. Our aim is to discuss how these and other issues present specific and unique challenges to educational historians in the United States. ${ }^{2}$

\section{The "Golden Era" in Educational History}

Some educational historians seem to miss the late 1960 s and 1970s. That passion is somehow lost. We don't know where we're heading. We don't know what we're doing. (conference participant, tape 4, p. 2)

Bring together a cross-generational group of American historians of education to talk about their field and the conversation is likely to turn to the "golden era" of the 1960 s and 1970s. Like most such perceptions of the past, the conversation is simultaneously about reconstructing an earlier era and trying to understand the present. In retrospect, the "golden era" of American educational history was notable in capturing the attention of social historians, educational and social science researchers, policymakers, school reformers, and, to a certain extent, the lay public. The educational historians of the 1960s and 1970s articulated a scholarship connected to historically significant social movements. They made this connection by asking provocative questions about the relationship of democracy to education, the role of schooling in the reproduction of social class, the origins and consequences of the bureaucratic organization of public schooling, the role of schooling in immigrant communities, and, to some extent, the struggles of people of color over access to schooling.

The historical scholarship of those decades was noteworthy because it told stories about the past and it attempted to reveal the historical roots of the educational crises of the 1960 s and 1970s. With much of their historical writing fueled by ideological and reformist passion, the revisionist historians generated attention from within and outside the historical profession. And, they elicited levels of dissension and dissidence that paralleled the ideological and scholarly conflicts that marked higher education in those decades.

There was an irony to the collaboration of past and present. The origins of the golden era began with an explicit plea to replace presentist models of educational history with questions and analyses firmly rooted in the past. Initially articulated by "cultural" revisionists Bernard Bailyn and Lawrence Cremin in the late 1950s and early 1960s, the relationship between past and present would become a source of considerable controversy. Bailyn (1960), who would soon become one of the country's preeminent colonial historians, began the debate by arguing that American educational history had been distorted by educators' desire to use the past to glorify the triumph of public schooling in the United States. In The Wonderful World of Ellwood Cubberley (1965), Cremin echoed and extended Bailyn's view by indicting previous generations of American historians and showed how to fashion a history of schooling that met the canons of late 20th-century historical scholarship.

With the publication of The Transformation of the School (1961), a history of progressivism in education that won the prestigious Bancroft Prize in American history, Cremin simudtaneously emerged as the country's best-known historian of education and worked to legitimate educational history among American historians. Bailyn and Cremin emphasized the need to rescue educational history from present-day educationists who drew a straight line from the colonial legislation mandating schools, to the common school movement of the 19th century, and then to the fullblown public education system of the mid-20th century. ${ }^{3}$

As happened in so many other areas of academe, the convulsions of the 1960s and early 1970s changed the direction of historical scholarship. What began as attempts to bring intellectual and scholarly respectability to the educational past and to make it a constituent part of intellectual, cultural, and social history quickly became overlaid with the desire to illuminate the roots of America's educational problems. As Michael B. Katz noted at the Spencer conference, the civil rights movement and the war on poverty

pointed to a need for a history that actually explained the current situation. The history of education as it was [then] written and understood actually made no sense whatsoever when one was thinking about what American education was like then and its problems. (tape 5, p. 12)

Acutely concerned about the relationship of the present to the nation's educational past, a group of young historians, loosely labeled as "radical" revisionists, went beyond Bailyn and Cremin. They looked to a new kind of social history that focused on ordinary citizens and the travails of historical outsiders. These historians wrote about the politics of education, broadly defined, asking questions about who gained and who lost, whose interests were represented, and who was marginalized during earlier periods of educational reform. As Michael Katz (1987) eloquently pointed out, a revolution took place in American educational history. Historians "rejected both the metaphor and the method that had characterized most constructions of the educational 
past" (p. 5). For decades educational history was "narrow, antiquated, and uninteresting ... a simple narrative of the triumph of benevolence and democracy [was] no longer ... taken seriously by any scholar" (p. 5).

Between 1968 and the late 1970s, radical revisionists, whose members were not always in agreement with one another, published a series of studies that collectively argued that:

- Americans have historically placed enormous expectations on what public schools can accomplish (Cremin, 1972; Perkinson, 1968);

- Schools have historically been designed to reproduce the existing social order (Bowles \& Gintis, 1976; Karier, 1975; Spring, 1976);

- Public school systems were created to assimilate and Americanize and had consistently discriminated against immigrants and minorities (Greer, 1972; Kaestle, 1973; Karier, Violas, \& Spring, 1973; Tyack, 1974);

- Public high schools were established for the benefit of the middle and upper classes (Katz, 1968);

- The bureaucratic organization of schooling was designed to inhibit working class achievement (Katz, 1971; Tyack, 1974);

- Vocational education was created as a device to curb working class and immigrant aspirations (Lazerson, 1971; Lazerson \& Grubb, 1974);

- Urban public school systems were organized in the image of "one best system" that denied the legitimacy of public participation in educational decision-making, undermined teacher professionalism, and rejected the validity of ethnic and racial cultural values (Tyack, 1974).

Few of the new wave of educational historians were comfortable with all of these claims. Bailyn was bothered in finding his calls for a new educational history being captured by those committed to blending past and present. However, the radical revisionists were self-consciously engaged in a scholarship of myth shattering. Except for Merle Curti (1959), previous generations of educational historians had typically glorified the triumphs of public education; the revisionists were prepared to criticize almost every major reform of the past. Taking advantage of an important shift in education schools during the 1960s and 1970s toward strengthening their academic credentials over the traditional teacher and administrator preparation programs, radical revisionist historians simultaneously aligned themselves with civil rights and educational reformers and claimed they were entitled to recognition from departments of history.

Other historians began to ask questions about this new educational history, challenging the empirical data, the ideological underpinnings, the conspiratorial tone, and, what the radical revisionists considered their greatest strength, their ability to project the past into the present (Kaestle \& Vinovskis, 1980; Lazerson, 1973; Ravitch, 1977; Vinovskis, 1985). Although sometimes overblown, much of the criticism struck home. Radical revisionists responded, showing little tolerance for conservative visions of America (Katz, 1987). But there were glaring absences in the revisionist histories. The working-class and minorities were often viewed as victims in historical conflicts, immigrants were almost exclusively from southern and eastern Europe and almost nothing was mentioned about Latinos, Asians, and Native Americans. Religious beliefs usually got short shrift or were treated as suspect influences. Although some mentioned the "feminization of teaching," few women appeared in these historical accounts (Tyack, 1974). Teachers either did not exist or lost power within the bureaucratic organization of schools. And, there was almost nothing about the internal dynamics of schooling, on what happened in classrooms, how children were taught, or what they learned. ${ }^{4}$

The radical revisionist historians believed that public education had been built through a series of concrete choicesto create high schools, to establish vocational training, to organize centralized bureaucracies-choices made on the basis of unequal political power in the interests of some groups over others. Their history implied that outcomes could have been different had power, wealth, and access been more equitably distributed. The way they wrote history, however, had a deterministic quality. Often the historians' conclusions seemed to be that the only way to improve schools was to change the nation's economic and social order, a message that offered little incentive to educational professionals in the field. ${ }^{\overline{5}}$

Was there a "golden era" in the writing of American educational history during the 1960s and 1970s? Yes, but not necessarily because of what the educational historians wrote. Rather, the golden era occurred because the historians rode two powerful waves of those decades. The first was the parallel and broader wave of revisionist writing in American social and political history. As part of this wave, the history of slavery and reconstruction and the origins of the Cold War were rewritten. Women's history and the history of African Americans emerged as vibrant entities. The application of social science techniques to historical studies opened a new history of ordinary people. Educational historians thereby joined a larger transformation that strengthened their work and gave them a scholarly identity within the community of historians.

Radical revisionists also gained attention by asking big questions about the roots of crises. It was an easy leap of faith to go from Jonathon Kozol's (1967) contemporary Death at an Early Age or the battles over decentralization and community control of schools to revisionist histories of schooling. But the supreme irony of the golden era was that radical revisionists gained attention by doing what previous generations of educational historians had done: They claimed an immediate connection to the present.

No doubt the radical revisionists of the $1960 \mathrm{~s}$ and $1970 \mathrm{~s}$ established an identity that was hard to match. Yet their most lasting contribution may be the historical writings that followed, many by their own students. The electricity surrounding the historical work of radical revisionists attracted a generation of educational historians whose work extended and modified their teachers' contributions and opened up fields previously barely noticed. In many cases, they generated new scholarship with greater degrees of sophistication. At the beginning of the 21st century, we have come to a fuller, though still incomplete, historical understanding of women's education (Lagemann, 1979; Rury, 1991), vocational education (Kantor, 1988; Powers, 1992), high schools (Labaree, 1997, 1988; Reese, 1995), teachers and teaching (Cuban, 1984; Rousmaniere, 1997), Mexican Americans (Donato, 1997; Gonzalez, 1990; San Miguel, 1987), African Americans (Anderson, 1988; Fultz, 1995a, 1995b, 1996; Perkins, 1987; Walker, 1996;), regional history (Leloudis, 1996), educational policy (Ravitch, 1995, 2000; Vinovskis, 1999), urban schools (Angus \& Mirel, 1999; Raftery, 1992), and 
the role of foundations in educational reform (Lagemann, 1989, 1999; Lagemann \& Shulman, 1999).

Almost all of these contributions directly and indirectly drew upon the work of the educational historians of the 1960 s and 1970 s, whether by embracing or criticizing it. The golden era, then, was many things, more varied and complex than the sketch we have drawn. Its legacy may be less in what was written and more in what followed. In the sections that follow, we turn to an analysis of where selected aspects of American educational history are heading.

\section{Writing the Educational Histories of People of Color}

On one level it seems that much has been written about people of color. There have been explosions in African American history, Asian American history, and of late, Chicano history. But when you look more carefully at their educational histories, very little has been done. (James Anderson, tape 6, p. 3)

Radical revisionist educational historians, in short, dealt a devastating blow to the traditional promotionalist paradigm for research in the history of education. Indeed, they challenged conventional wisdom about educational history and asked provocative questions about the purpose and function of schooling. Yet, there was an undeniable and largely unrecognized irony to their work. As they documented the inequities of education in America and detailed the impact of race, class, ethnicity, and gender on the development of schooling, almost no educational historians of color (male or female) participated in the writing of these revised histories. While some educational histories of African Americans were written by African Americans (e.g., Bullock, 1967), few scholars of color were in positions to write about their educational past.

The presence of and research by scholars of color has increased over the past two decades, but scholars of color continue to constitute a very small percentage of the field. It was thus not surprising that the Spencer conference participants raised the question: Who will write the educational histories of peoples of color? Although on the surface this question seems relatively benign, Robert Lowe pointed out that the question ultimately asks "whether White folks should continue to be imperialists" in the field (Lowe, tape 6, p. 1).

White educational historians of the 1960 s traditionally enjoyed privileged positions in academe that in essence "authorized" them to write, in part, about people of color in U.S. schools. The question "who shall write" quickly became a discussion about what it means for educational historians of color to participate in the field, how they can improve their representation, and how they envision their role in determining the future of historical research in education. Such an inquiry may raise issues of academic freedom and political correctness, implying that White scholars should not write the educational histories of people of color. We argue, however, that the new direction of American educational history is not about excluding White scholars or trying to create a single line of interpretation. It is a call for increased and more meaningful opportunities for scholars of color to participate, to publish their work, and to have a voice in the direction of American educational history.

Interpreting what this new direction means invites a substantial diversity of opinions. How, for example, does one distinguish between "outsider" and "insider" historical knowledge? In anthropology, that question arises in the ongoing debate about the art of balancing "emic" and "etic" voices, a question that mirrors the efforts of historians to try to reconcile subjectivity and objectivity in educational research. Outsiders point out that insiders tend to take certain issues and phenomena for granted and that outsider perspectives can mitigate this. Non-American historians writing about American history, for example, may bring insights to their work that American historians need to consider. Still, outsider information alone can limit or circumscribe research efforts. Insider knowledge can be invaluable when historians attempt to understand the motivations, intentions, and actions of historical actors.

The expansion of opportunities for educational historians of color has already gone far to correct the neglect and misrepresentations of past scholarship. As one example, James Anderson's (1988) The Education of Blacks in the South, 1860-1935 altered perceptions of how African American education developed in the post-Civil War South by exposing the ways White Northern philanthropists and industrialists collaborated with Southern racists to create a second-class system of schooling, and the ways African Americans challenged that system-themes that have become central to understanding the history of segregated schooling. The critical role that African American women and teachers played in sustaining education in a segregated environment has finalfy come under examination in ways that show how and why schooling became so central to the Black community.

Vanessa Siddle Walker (1996) has also challenged conventional wisdom about school segregation in the South. In her study of a rural North Carolina community, Walker argues that African American educators drew upon community support to create environments of teaching and learning that motivated students to excel, countered larger racist messages that devalued African Americans, and reframed those messages to make African American children believe in their ability to achieve. The quality of education, she argues, eroded after the 1960s, when schools became racially integrated.

Linda M. Perkins's scholarship has added to our understanding of the unique positions of African American women within the Black community and American educational history. Perkins argues that early-educated African American women were central to the development of their communities. In her book, Fanny Jackson Coppin and the Institute for Colored Youth, 1837-1902 (1987), Perkins develops this thesis and discusses one of the earliest Black women college graduates and her leadership of the Institute for Colored Youth in Philadelphia, a prominent private classical high school at the end of the 19 th century and early 20 th century.

Likewise, Michael Fultz's (1995a, 1995b, 1996) work on the history of African American teachers in the South has contributed to the increased depth of this scholarship. Fultz examines the post-emancipation period through the early 1960s and explicates the policy context that conditioned Black teachers' classroom experiences as well as the specific issues that Black teachers faced in their school and extracurricular activities. Fultz's work attempts to highlight, in part, the largely hidden centrality of African American teachers to racial uplift, demonstrating how such concerns as the improvement of Black teacher education, the elimination of salary discrimination, and the development of Black teacher 
organizations were directly linked to the overall Black educational enterprise.

Latino historians of education have similarly contributed to the field. They have been demonstrating ways in which unequal educational opportunities played out for Mexican Americans in the Southwest. For example, Guadalupe San Miguel's (1987) "Let All of Them Take Heed," Mexican Americans and the Campaign for Educational Equality in Texas, 1910-1981 looks at the Mexican American struggle for equal

\section{... we risk neglect and rejection by the other, and are often seen either as antiquarians irrelevant to the burning educational issues of our times or as "presentists" with little appreciation of the uniqueness of the past}

schools in Texas, the origins and statewide struggles for educational equality, the leadership roles of the League of Latin American Citizens (LULAC) and the G.I. Forum, and how Mexican Americans challenged discriminatory educational practices in the state. One theme that recurs throughout the book is the manner in which school segregation facilitated the reproduction of the existing caste-like system of the dominant-subordinate relationship between Mexican and White communities.

Gilbert Gonzalez (1990), in Chicano Education in the Era of Segregation, examines the schooling experiences in the Southwest during the first half of the 20th century. Like San Miguel, Gonzalez considers the expanding segregation of Mexican American children. However, he also looks at the relationship between the political/social exigencies of the dominant (White) society and the nature and impact of IQ testing, curricular differentiation, Americanization, and vocational education during the first half of the century. In the end, Gonzalez argues that the educational separation of Mexican American children corresponded with and reflected the specific economic interests of White communities throughout the Southwest.

Rubén Donato $(1997,1999)$ challenges conventional wisdom that Mexican Americans were passive victims accepting their educational fates. He argues that, similar to the Black movement, Mexican Americans were actively seeking educational justice for their children during this period, and on some occasions were primary educational decision-makers. Their struggle, however, went largely unnoticed by most "Americans" in the United States.

These contributions have initiated a revolution in understanding the educational history of communities of color. But much still needs to be done. There is, for example, almost no synthesis or intersection across the communities; much of the history has been written in isolation-with Blacks, Latinos, Asians, Native Americans and others writing from or about only their particular communities. Most scholars work in iso- lation; very few connect with researchers from other communities of color, a phenomenon reinforced by the academic culture of specialization. For most educational historians of color, the concerns of other communities of color, as well as the connections between class, race, gender, and schooling, seem to fall outside of their research agenda.

The research possibilities inherent in the similarities and differences in the educational experiences of some peoples of color are enormous. Take, for example, the African American and Mexican American experience. Very little is known about what African Americans and Mexican Americans have in common and or how their histories diverge. These two groups both experienced inferior public schools, limited access to colleges, and limited legal means to address inequalities. While Mexican Americans in the first half of the 20 th century could "legally" attend White colleges, very few actually attended. For instance, half of all 17-year-olds in the United States graduated from high school in 1940 (Kirst, 1984, p. 8). During this period, Mexican Americans rarely went to public school beyond the sixth grade. Eighthgrade graduation was a major accomplishment. In the South, where the vast majority of African Americans lived during the same period, Jim Crow legally denied them access to White colleges, but they could-albeit in limited numbersattend historically Black institutions. The distinction would prove important in the war African Americans waged against de jure segregation.

The whole question of school segregation and the battles against it takes on a new dimension when cast comparatively across communities of color. As Guadalupe San Miguel pointed out during the Spencer conference, the "White status" of Mexican Americans did not allow them to use the same litigation that facilitated the integration of African Americans into predominately White schools. Mexican Americans had to develop novel strategies in order to challenge unequal education and school segregation.

The paucity of cross-cultural comparisons/analyses parallels the general lack of quality educational histories of people of color. Although changing, most historians of education typically conceive of "minority" educational histories very narrowly so as to include only the schooling of African Americans; they write and teach the histories of people of color primarily within a Black/White context. Few history of American education courses and too few scholarly writings discuss the experiences of Asian Americans, Native Americans, or Latinos. ${ }^{7}$

For all the tremendous growth in research on the educational histories of people of color, this area of inquiry remains very small, understudied, and insufficiently explored. Multiple perspectives are needed to provide healthy, viable, and exciting ways to enrich the field. Intersections of experience among communities of color have the potential to improve research and teaching. To accomplish this, historians of color must be actively involved in deciding and shaping the content and direction of future scholarship on the history of American education.

\section{The Relationship Between History and Educational Policy}

I am not sure it should be a long-term reform strategy for history to influence policy. But I am certainly willing to work with the idea that if we are silent about policy we are not 
going to get too far. We have to at least put some of our stories out there. (conference participant, tape 14, p. 13)

Educational historians have passionate discussions about the nature of their vocation, the utility of their work, and the audience(s) for their scholarship. One of the most contentious and complex issues is the relationship between historical research and educational policy. Few historians think in terms of immediate "lessons." Neither their disciplinary training nor their historical findings prepare them to offer concrete and specific solutions to contemporary problems. Nonetheless, most educational historians believe that they are in privileged positions to offer the "long view" of policy decisions, and that their work can and should inform current policy debates. Conflict emerges among historians of education when they ask the following kinds of questions: Are there policy lessons one can learn from educational history? Are there ways to critically interpret the past and apply it to current policymaking? If so, how can educational historians participate in the policy arena in meaningful ways?

Even as educational historians debate these questions, they are in almost unanimous agreement about their marginal impact on educational policy. They have difficulty finding a voice in policy discussions, especially at federal and state levels. On those few occasions when educational historians participate, they are often asked to provide simple answers, a variation of the "30-second" sound bite. As one Spencer conference participant noted, "I'm not sure whether there's a stable point for us where we can be engaged in policymaking at a formative level long enough and deep enough to actually bring the perspective of history to bear" (conference participant, tape 13, p. 11). The desire to participate is thus often hampered by participation that is limited to the delivery of simplistic, meaningless, and disingenuous phrases.

Educational policymakers are often interested in using "historical perspectives" primarily to advance their own agendas. Used in this way, educational history may be relevant for its advocacy potential. When the historical evidence is reduced to simplistic conclusions, the existence of multiple and often competing or contradictory interpretations of historical data-the very stuff of sophisticated historical scholarship - gets converted into policymakers choosing the history that best suits their goals. As John Rury noted at the conference:

You tell one story. Somebody else tells another. It's not like there's one answer that comes out of these stories.... The fact is that policy makers choose whichever one they want to use to serve their purposes, no matter what history you tell them. We have to get over the notion that there's going to be one historical answer that comes out of this. I think we also have to deal with the fact that a lot of the times they're going to use the history that they want to form their policies. (Rury, tape 14, p. 12)

The issues are further complicated for educational historians by the multiple meanings and levels of educational policy. For some educational historians, involvement with educational policy typically means understanding the evolution and implementation of policies or even direct engagement in the policymaking arena. Participation entails the historical analysis or actually working on policies such as Title I and Head Start, or taking positions in federal or state depart- ments of education, adding to one's historical scholarship the immediacy of policy practice (Vinovskis, 1999).

Grassroots-oriented educational historians tend to think of engagement at the local level, with community groups, teachers and school-based administrators, or school districts. Their historical scholarship can then become a useful tool that enables policymakers, practitioners, and advocates to see how communities changed over time, to understand the persistence of certain educational dilemmas, and to appreciate the ways in which past events and phenomena inform present conditions and future decisions (San Miguel, 1987; Walker, 1996). Even in this arena, however, the primary criterion for acceptance may be the ability to convert one's historical scholarship into present-day advocacy positions.

For all its dilemmas, a small number of educational historians have been applying their scholarship to provide insights and, on occasion, policy direction to contemporary issues. The most prominent of these have been Maris Vinovskis (1999), Diane Ravitch $(1995,2000)$, and Ravitch and Vinovskis (1995). Ravitch, in particular, has often drawn upon her historical analysis of "failed school reform" to show how reformers have undermined the schools' capacities to achieve quality education for all students and to suggest what kinds of reform efforts are more likely to achieve that goal. As another example, a collection of essays to celebrate the College Board's centennial anniversary (Johanek, in press) tries to illuminate the ways in which the Board has and continues to mirror the major dilemmas of American education. In another case, Kenneth Ludmerer's (1999) history of medical education in the 20th century seeks an immediate connection between the historical evolution of market forces into medical education and the degradation of that education. And, in perhaps the most interesting attempt to show the continuing saliency of history in the present, David Tyack and Larry Cuban (1995) have emphasized the "grammar" of schooling, those things that were historically created but which over time became part of our assumptions about schools.

In terms of directly shaping policy, such efforts appear to have little impact, except insofar as they give evidence to policymakers already decided upon their goals. History's power in the policymaking arena tends to be directly proportional to its ability to strengthen existing advocacy positions. This situation makes historians nervous and apprehensive about the misuses of educational history. The more historians seek to shape the policy field, the more the "policy tail" can wag the "historical dog" (Rury, tape 5, p. 26), with policymakers prescribing or dictating the foci of educational history, the issues to be studied, and the political lenses and ideologies that inform the scholarship.

One way out is to hold fast to the notion that educational historians offer "historical perspectives," keeping a kind of arm's length distance from the policy process as a way of protecting the authenticity of the past. As one Spencer conference participant suggested, educational historians need to be careful about their involvement in the policy arena because they often become advocates of specific reforms, are likely to distort the past in the process, and run the risk of trying to become what they are not, "policy analysts ... political scientists, anthropologists, sociologists, [or] whatever it is that is needed" (conference participant, tape 13, p. 23). By remaining historians and letting the questions arise from the past rather than from present dilemmas, educational 
historians may be less attractive to policymakers but more substantial contributors to the discipline of history.

This view is not likely to win favor among many, if not most, educational historians. The thorny issues of the present are too often generative of provocative and innovative history. Given the particular role of educational historians within education schools, the opportunities to ask historical questions about current issues are too exciting and too important to leave unexamined. School choice and educational alternatives, the construction and deconstruction of educational bureaucracies, religion and values in education, and community-based schooling have historical roots, and it is the responsibility of educational historians to examine how and why they emerged (Tyack \& Cuban, 1995). These topics have direct, tangible, and substantial impact on our educational lives, and educational history can inform policy debate and decisions about them.

Beyond that, there are more direct ways of bringing knowledge of the past to the present. Taking advantage of their places within education schools, educational historians can engage in efforts to revise curriculum, help teachers think about the historical nature of a multicultural society, and work with school boards and reformers on the historical reasons behind the creation of urban educational bureaucracies. Such efforts bridge the boundaries between history as a discipline and history as a way of rethinking the present.

Educational policymakers and advocates may not want to make the connections between history and policy and educational historians will have to contend with the arm's length position at the policy debate table. But educational policies are proposed and implemented in the context of historical moments. Invariably, the policies rest on assumptions about the past; they rest on the stories people believe about the past. Educational historians have an obligation to thrust their stories into the policy arena for if they do not, the stories that become the common view will be told by others who often have little stake in the integrity of historical scholarship. Or, even worse, their stories will go unnoticed altogether.

\section{Revising the History of Higher Education}

How many fundamental questions were asked about the nature of higher education during the 1960s; what higher education was doing, what knowledge was about, and why people wanted to be educated? (Julie Reuben, tape 8, p. 15)

American higher education's past has typically been treated as separate from and marginal to the broader field of educational history. Higher education thinks of its mission as different from elementary and secondary schooling; its private institutions are honored, whereas Americans are more ambivalent about private elementary and secondary schools. Most histories are studies of individual institutions, usually written in celebration by long-term faculty members; few would consider analogous histories of school districts sufficient to understand the educational past. Most educational researchers do not consider academe's history relevant, even though it so obviously shapes their work. This separation and marginalization is being dramatically altered, however, in response to the cascade of recent criticism of higher education and the current trend toward thinking of kindergarten through university as one system.

For more than 35 years, higher education's past has been dominated by three books: Richard Hofstadter and Walter P.
Metzger's (1955) The Development of Academic Freedom in the United States; ${ }^{8}$ Frederick Rudolph's (1962) The American College and University: A History; and Lawrence Veysey's (1965) The Emergence of the American University. Although each differed in its emphases, taken together they told a story in defense of higher education's need to protect the search for scientific truth against religious and populist interventions through tenure and academic freedom and the development of disciplinary-based research. Beginning in the late 1960s, but gathering strength in the following decades, this sense that American higher education would function best if supported fiscally but left organizationally unfettered came to seem wildly out of step with the sharp criticisms increasingly leveled at colleges and universities.

The first shift lay in including the majority of people enrolled in higher education-women. The publication of Barbara Solomon's (1985) In the Company of Educated Women focused attention on how women fought for access to college, on their collegiate experiences, and on college's effects on women's subsequent lives (Eisenmann, 1997). Other studies soon followed describing the ways women faculty negotiated their professional and personal lives (Fitzpatrick, 1990; Palmieri, 1995; Rosenberg, 1982; Rossiter, 1982, 1995), on women higher education administrators (Bashaw, 1999; Horowitz, 1994; Nidiffer, 2000), on women's colleges and women students (Gordon, 1990; Horowtiz, 1984, 1987), and on the education of Southern gentlewomen (Farnham, 1994). Although these and other studies have not yet been woven either into a comprehensive history of women in higher education or into the ways women's and men's higher education experiences can be historically compared, the transformation from an ignored to a central place in higher education has occurred.

The traditional history of the research universities is also being rewritten. One revision focuses on the growth of a research economy - where research funding came from, how it was spent, and how the purposes and behaviors of research universities shifted as the sources and amounts of money changed. The very growth of the research economy was itself a cause of many of higher education's subsequent tensions and travails (Geiger, 1986, 1993; Graham \& Diamond, 1997; Lagemann, 1989, 1999; Lazerson, 1998).

A second revision reshapes an old story-the triumph of scientific research. Julie Reuben's (1996) The Making of the Modern University converts this triumph into a problematic by showing how "unbiased" scientific research constituted a loss of ethical and moral purposes. By the 1920s, "value-free" science had pushed such purposes to the oftenmarginalized humanities and, even more consistently, to the extra-curriculum and the managers of "student life." Like Lawrence Levine's (1996) The Opening of the American Mind, a study of the continual altering of the collegiate curriculum under the impact of different kinds of students, Reuben's work speaks to an audience that wonders about moral values and the ethos of higher education.

Despite the fact that higher education's greatest success may reside in making its certification system the primary gatekeeper to material goods and social status, the historical evolution of that process has been understudied. Some historians have shown how European immigrants sought access to college and how "selective" admissions was used to limit that access (Synnott, 1979; Wechsler, 1977). David Levine (1986) has offered perhaps the most intriguing argu- 
ment, that during the 1920 s and 1930s, higher education became identified with America's "culture of aspiration" leading to the growth of existing institutions, the founding of new ones, and a sharpened emphasis on vocational training and certification. This work is clearly only the tip of the iceberg, especially since we still know little about how peoples of color were limited in their use of higher education and the ways they advanced through it, issues that are central to current debates over affirmative action and the outcomes of schooling (Anderson, 1988; Harlan, 1983).

Current reformers' efforts to think of the educational system as an integrated whole have not been reflected in studies of the historical relationships between higher education and elementary and secondary education. The evolution of an educational ladder from elementary and secondary schooling to college, for example, is not well developed. Nonetheless, recent efforts to show how the College Entrance Examination Board and the Educational Testing Service became mediating institutions between secondary and higher education hold promise that historians will begin to think of the educational system as an integrated whole rather than a simple sum of its constituent parts. This new research trend is thinking about an American educational system rather than being limited to its higher education constituent (Johanek, in press; Lemann, 1999).

Historians are also turning to the vocationalization of higher education. One manifestation has been histories of professional education. Medical education is the most studied, in part, because it brings together scientific discoveries and clinical applications with the organization of knowledge and control over access to a prestigious profession. It also benefits from a "turning point" document, the famous Flexner Report (1910) that both urged and prophesized dramatic changes in the education of medical doctors (Ludmerer, 1985, 1999). Other professions have begun to develop their own histories-teaching, nursing, law, business, engineering (Auerbach, 1976; Johnson, 1974; Levin, 1994; Noble, 1977; Schlossman \& Sedlak, 1988). As important as such studies are, they tend to treat each profession as a separate entity rather than connecting them to the broader vocationalization of higher education, again making it difficult to find audiences outside the narrow specialization (Kimball, 1992).

The histories of community colleges and of state systems of higher education are understudied. Community college historiography has tended to thrash around in debating the historical accuracy of Burton Clark's notion of community colleges as "cooling out" institutions, whether the colleges have primarily served as "dead-ends" or as way stations to higher social and economic status (Brint \& Karabel, 1989). Recent historical scholarship has looked at community colleges as politically important institutions to local communities (Dougherty, 1994; Hutcheson, 1999). The numerical dominance of public systems of higher education has not been given its due by historians. In light of the controversies over costs and the politicization of these systems, historians have been compelled to look at how they came into being and the ways they have evolved (Link, 1995). They will also have to look at how institutions engaged their local communities (Diner, 1980; Schlossman, Sedlak, \& Wechsler, 1998).

Much of the current debate over the quality of higher education builds on assumptions about the 1960s and 1970 s, and it was only a matter of time before those decades would receive historians' attention. Whether the historical assessments will designate the events of those years as watersheds, transient, or containing elements of both, remains to be seen. Certainly the issues posed were significant-access, redefining knowledge, relationships between institutions and local communities, reorganizing institutional governance, secret versus open research, in loco parentis responsibilities, financing, and the expansion of public systems have retained their saliency into the present (Horowitz, 1987; Reuben, in press).

Histories of individual institutions and institutional leaders will continue to be produced (Geiger, 2000; Hershberg, 1993; Horowitz, 1994; Mayer, 1993; Potts, 1992). But the more important development is likely to be studies of the "ecology of institutions," the ways colleges and universities sharing the same geographical areas developed. The breakthrough contribution is Richard Freeland's (1992) Academe's Golden Age, a comparative examination of Massachusetts universities between 1945 and 1970 that emphasizes the power of the post-war research culture in the institutional search for status and money. Substantially more historical scholarship will be necessary to understand how market forces shaped institutions in metropolitan areas like New York or Atlanta.

Current interests in religion and teaching are sparking new historical studies. Religiously based institutions have been central to higher education, but until recently largely neglected by historians (Gallin, 2000; Marsden, 1994; Ritterband \& Wechlser, 1994). We are only beginning to understand how students with strong religious orientations negotiated their ways through non-religious institutions or how the rise of liberal Protestant universities affected nonProtestant participation and experiences in such institutions. In Kathleen Mahoney's terms, how, for example, did Boston's Catholics become Harvard graduates (Mahoney, in press)? Recent debates about collegiate teaching have already led to one historical study, focused on Stanford, that finds that institution's instructional reforms were invariably subordinated to the primacy of research (Cuban, 1999).

Taken together, the new scholarship suggests that the history of higher education is in the midst of a dramatic revision. A field once dominated by a few books now boasts a multiplicity of studies that direct attention to the past and to the present. The conversation between historians and contemporary researchers remains muted, but recent evidence suggests that it may grow, particularly since so much of what contemporary-minded analysts believe is based upon assumptions about the past.

\section{A Gendered History of Education}

Do you agree that women's educational history has produced some good studies but has not affected central conversations in the field? (conference participant, tape 7, p. 9)

Few fields have grown more rapidly or been more innovative than the history of women. Women's educational past has been part of this growth, drawing attention to a wide range of educational experiences and making comparisons between male and female education (Lagemann, 1979; Tyack \& Hansot, 1990). The historical study of women in education has also been boosted by a shift in focus among contemporary educational reformers from broad policy initiatives to concern about the internal dynamics of schools and 
classrooms, emphasizing teachers, teaching, and learning. The shift has furthered interest in the historical experiences of women teachers (Hoffman, 1981; Prentice \& Theobald, 1991; Warren, 1989). Still, as Spencer conference participants suggested, scholarship on the historical experiences of women in education has tended to be additive rather than integrative and thus has not substantially revised the history of education as a scholarly field.

Gender-based studies of elementary and secondary schooling, like Tyack and Hansot's (1990) Learning Together, reveal both the power of gender-differentiated roles, for example, in the shaping of the extracurriculum and vocational training, and the extent to which boys and girls genuinely learned together. Two powerful themes have emerged. First, public schools historically were probably more egalitarian by gender than much of the rest of society. Second, vocational education, which began as an effort to keep boys from dropping out of school and to prepare them for an industrial workforce, was most successful in enrolling girls in secretarial and clerical programs (Kantor, 1988; Powers, 1992; Rury, 1991).

Historians of education have also been active in presenting the experiences of teachers and teaching. Much of this scholarship reveals how deeply embedded in their communities many teachers once were, furthering close connections between families and schools. Although this literature sometimes reflects a "world we have lost" view, its importance in showing the ways bureaucratization and professionalization and the changing nature of urban neighborhoods redefined the role of teachers, their self-definition, and the relationships between communities and schools cannot be underestimated (Altenbaugh, 1992; Blount, 1998; Weiler, 1998). The depth of the connection between African American teachers and their communities in the era of de jure segregation is made abundantly clear in Vanessa Siddle Walker's (1996) Their Highest Potential, which effectively asks scholars to rethink the era before Brown $v$. Board of Education. The ethos of self-improvement among African American educators, most of whom were women, similarly shows how teachers' aspirations for themselves reflected the wider aspirations of their communities (Fultz, 1995a, 1995b, 1996; Perkins, 1987). In sharp contrast is the stressful story of how teachers and parents moved toward more oppositional positions over time (Cutler, 2000), and of the ways the organizational structure of urban school systems shaped teachers' attitudes and behaviors (Rousemaniere, 1997). Teaching as pedagogy has tended to be neglected, a phenomenon not limited to historians. One notable exception is Larry Cuban's (1984) How Teachers Taught, which argues that elementary school teachers, overwhelmingly women, were more likely to institute progressive pedagogical reforms than their secondary school, primarily male, counterparts, although the connection between the two levels of schooling and the gender of the teachers is unexplored.

Women's higher educational experiences have received substantial attention (see the earlier section, "Revising the History of Higher Education"). These studies tend to fluctuate between emphasizing discrimination against women and honoring the effectiveness of women's actions on their own behalf. The breakthrough work by Barbara Miller Solomon (1985) stressed the struggles over access, the treatment of women as second-class citizens within co-educational institutions, and the ways that women joined together to achieve entry into college. Other studies have traced similar themes (Eisenmann, 1997; Griffin, 1984; Lasser, 1987; Perkins, 1993).

Despite marvelous work over the last few decades, the history of women's higher education has left many questions unexamined. Helen Horowitz's (1987) portrayal of students over time depicts women as replicas of their male counterparts, but a closer knowledge of how women actually behaved remains elusive. How did women students at co-educational institutions affect those institutions historically? What have been the consequences for men and women since women have become the majority in the undergraduate student body? Have there been differing views of knowledge between women and men and, if so, with what consequences? What have been the relationships between women's substantial enrollments in the liberal arts, education, and nursing, all low-cost programs of study, and the predominantly male programs in engineering, the sciences, and business? Such questions are difficult to answer, but they are necessary to move toward a more synthetic understanding of women's educational experiences (Clifford, 1995; Nerad, 1999).

A gendered view of the educational past that brings women's experiences to the fore may well transform the ways we understand the historically significant (Eisenmann, 1998). Such a history, for example, is likely to be less dependent upon large interpretive frames like bureaucracy and policy formulation to carry the story, and more focused on the "lived life in schools" for both students and educators. This kind of history, as Kate Rousmaniere noted at the Spencer conference, will be more dependent on "piecing together tiny little nuclear pieces" in order to get a sense of the whole (tape 7, p. 4). This approach to the past means greater attention to how life and community experiences shape behaviors and choices and draws more upon personal life rather than viewing schools as separate and personally neutral institutions. Since the trends in present-day educational reform influence historical research, this history will naturally lead from teachers teaching to the ways students learned and to the interrelationships between teacher behaviors and student learning. A view of the educational past from within schools and communities, one that evolves from the nature of women's experiences, may well be the most transforming of the historical scholarship on the horizon.

\section{Conclusion}

In this article we have shown that American educational historians face numerous challenges in their field. We gave a brief background of the "golden era" of the 1960s and 1970s in American educational history, where educational historians of color are situated in the field, the delicate relationship between history and policy, revisions in the history of higher education, and the educational histories of women. Within the context of these discussions, concerns about audiences and speaking simultaneously to the past and present remain.

In addressing issues of race/ethnicity, policy, higher education, and gender, educational historians understand the difficulty of having to talk about the past and present without marring a "genuine appreciation" of history. Indeed, those who look in both directions run the danger of being "presentists" to their colleagues in history departments. And, if they do not make connections to the present, their 
scholarship runs the risk of being irrelevant to their education peers. Nonetheless, we believe that there are too many provocative contemporary educational issues that have deep historical roots, and that educational historians can and should engage in these issues in order to make important contributions to current policy and practice.

All historians do not need to be equally adept in past and present conversations. Some historians of education find the past more congenial or are unfamiliar with current educational issues. But there are those who are well versed in contemporary educational affairs and look at historical moments as windows of opportunity to make connections to the present. These voices need to be heard by school people, their peers in the academy, and policymakers at the state and federal levels.

As we look back to the 1960 s and 1970 s, radical revisionist educational historians made important contributions to the field. We recognize their work because it was this group that raised questions that few scholars attempted to discuss before them. In contrast to how educational history had been written, radical revisionists raised questions of power and control in American public schools. They focused on how some groups won or lost in the schooling process, how some groups benefited from high schools, how some groups were channeled into vocational training, and how some groups were marginalized in the decision-making process in urban schools. But as we pointed out, much of their historical writing was incomplete. We had a superficial understanding about the African American experience in schools and almost nothing was mentioned about Native Americans, Asians, and Latinos. The significance of religion got shortchanged and we knew very little about what happened to children in classrooms, how they were taught, or what they learned.

It was those who came after the radical revisionists who provided better insights about women's education, vocational education, high schools, teachers and teaching, higher education, Latinos, African Americans, regional history, educational policy, and urban schools. While there are still only a small number of educational historians of color, for example, much has been accomplished, with the most pressing issue being the paucity of cross-cultural comparisons and the absence of historically collaborative work. Our challenge, then, is for educational history as a field to engage in a simultaneous conversation with a diversity of audiences, and to engage in research that brings together areas typically kept separate-gender, peoples of color, higher education, policy, elementary/secondary education, schools, and communities-to broaden and deepen our knowledge of the educational past and the ways that it enriches our understanding of the educational present.

\section{Appendix}

$\begin{array}{ll}\text { "New Directions in the History of Education" conference participants: } \\ \text { James Anderson } & \text { Linda Eisenmann } \\ \text { Barbara Beatty } & \text { Barbara Finkelstein } \\ \text { Geraldine Joncich Clifford } & \text { Michael Fultz } \\ \text { Larry Cuban } & \text { Roger Geiger } \\ \text { Ruben Donato } & \text { Gilbert Gonzalez } \\ \text { Jack Dougherty } & \text { Lynn Gordon } \\ \text { Greg Dubrow } & \text { Karen Graves }\end{array}$

Elizabeth Hansot

Harvey Kantor

Michael B. Katz

David Labaree

Ellen Condliffe Lagemann

Marvin Lazerson

James Leloudis

Robert Low

Kathleen Mahoney

Victoria-Maria McDonald

Jeffery Mirel

Theodore Mitchell

Linda Perkins
William Reese

Julie Reuben

Kate Rousmaniere

Gualdalupe San Miguel

Brian Sevier

Wayne Urban

Maris Vinovskis

Calley Waite

Keith Whitescarver

Joy Willamson

Jonathan Zimmerman
Daniel Perlstein

David Tyack

Spencer Administration participants include Patricia A. Graham, Catherine Lacy, John Rury, John Willams, Ramona Thomas, and Doris Fisher.

We are grateful to the Spencer Foundation for funding this conference. The data presented, the statements made, and the views expressed are solely the responsibility of the authors.

We would also like to acknowledge Brian Sevier for his assistance in this article.

\section{Notes}

\begin{abstract}
${ }^{1}$ Throughout the paper we quote from recordings/transcripts of various sessions at the "New Directions in the History of Education" conference funded by the Spencer Foundation and held on March 30-31, 2000, at Stanford University. Almost all sessions were recorded and transcribed. In the recordings/transcripts, however, it was difficult to diskern who was speaking in group sessions. When we quote from discussions we give credit to a "conference participant" because we were unable to recognize the person's identity. We use names of individuals when their identity was recognized.

${ }^{2}$ The historian's dilemma is neither new nor unique to historians. See Lagemann (2000).

${ }^{3}$ Richard Hofstadter and Walter P. Metzger's The Development of Academic Freedom (1955) was a parallel attempt to do for higher educational history what Bailyn and Cremin were doing.

${ }^{4}$ There were exceptions to the overall tone of the revisionists' writings. See David Tyack's (1976) Ways of Seeing.

${ }^{5}$ Given the thrust of their analyses, it was not surprising that a number of the historians shifted from an initial focus on the history of schools to histories of social policy. See, for example, the evolution of Michael Katz's work from schools $(1968,1971)$ to poverty $(1983)$ and welfare (1986) and of Marvin Lazerson's from schools (1971) to family and children's policies (Grubb \& Lazerson, 1982).

${ }^{6}$ In at least one case, the collaboration of a revisionist historian and his former student resulted in a substantially changed tone and interpretation of the educational past. Contrast David Tyack's The One Best System (1974) to David Tyack and Larry Cuban's (1995) Tinkering Toward Utopia. See also the differences between Lazerson (1971) and Lazerson (1987).

${ }^{7}$ See the emerging work about African Americans/Latinos by Victoria-Maria McDonald.

${ }^{8}$ This was republished as Hofstadter (1961) and Metzger (1961).
\end{abstract}

\section{References}

Altenbaugh, R. (Ed.). (1992). The teacher's voice: A social history of teaching in twentieth century America. New York: Falmer Press.

Anderson, J. (1988). The education of blacks in the south, 1860-1935. Chapel Hill: University of North Carolina Press.

Angus, D., \& Mirel, J. (1999). The failed promise of the American high school, 1890-1995. New York: Teachers College Press.

Auerbach, J. S. (1976). Unequal justice: Lawyers and social change in modern America. New York: Oxford University Press.

Bailyn, B. (1960). Education in the forming of American society: Needs and opportunity for study. New York: Vintage Books.

Bashaw, C. (1999). "Stalwart women": A historical analysis of deans of women in the south. New York: Teachers College Press. 
Blount, J. (1998). Destined to rule the schools: Women and the superintendency, 1873-1995. Albany: State University of New York Press.

Bowles, S., \& Gintis, H. (1976). Schooling in capitalist America: Educational reform and the contradictions of economic life. New York: Basic Books.

Brint, S., \& Karabel, J. (1989). The diverted dream: Community colleges and the promise of educational opportunity in America, 1900-1985. New York: Oxford University Press.

Bullock, H. A. (1967). A history of Negro education in the south: From 1619 to the present. Cambridge: Harvard University Press.

Clifford, G. J. (1995). "Equally in view:" The University of California, its women, and the schools. Berkeley: University of California Press.

Cremin, L. A. (1961). The transformation of the school: Progressivism in American education, 1876-1957. New York: Knopf.

Cremin, L. A. (1965). The wonderful world of Ellwood Patterson Cubberley: An essay on the historiography of American education. New York: Teachers College Press.

Cremin, L. A. (1972). American education: Some notes toward a new history. Bloomington, IN: Phi Delta Kappa International.

Cuban, L. (1984). How teachers taught: Constancy and change in American classrooms, 1890-1980. New York: Longman.

Cuban, L. (1986). Teachers and machines: The classroom use of technology since 1920. New York: Teachers College Press.

Cuban, L. (1999). How scholars trumped teachers: Change without reform in university curriculum, teaching, and research, 1890-1990. New York: Teachers College Press.

Curti, M. E. (1959). The social ideas of American educators. Paterson, NJ: Pageant Books.

Cutler, W.W. (2000). Parents and schools: The 150-year struggle for control in American education. Chicago: University of Chicago Press.

Diner, S. J. (1980). A city and its universities: Public policy in Chicago, 1892-1919. Chapel Hill: University of North Carolina Press.

Donato, R. (1997). The other struggle for equal schools: Mexican Americans during the Civil Rights era. Albany: State University of New York Press.

Donato, R. (1999). Hispano education and the implications of autonomy: Four school systems in Southern Colorado, 1920, 1963. Harvard Educational Review, 69(2), 117-149.

Dougherty, K. J. (1994). The contradictory college: The conflicting origins, impacts, and futures of the community college. Albany: State University of New York Press.

Eisenmann, L. (1997). Reconsidering a classic: Assessing the history of women's higher education a dozen years after Barbara Solomon. Harvard Educational Review, 67(4), 689-717.

Eisenmann, L. (Ed.). (1998). Historical dictionary of women's education in the United States. Westport, CT: Greenwood Publishing Group.

Farnham, C. (1994). The education of the southern belle: Higher education and student socialization in the antebellum south. New York: New York University Press.

Flexner, A. (1910). Medical education in the United States and Canada: A report to the Carnegie Foundation for the Advancement of Teaching. New York: Carnegie Foundation.

Fitzpatrick, E. (1990). Endless crusade: Women social scientists and progressive reform. New York: Oxford University Press.

Freeland, R. M. (1992). Academia's golden age: Universities in Massachusetts, 1945-1970. New York: Oxford University Press.

Fultz, M. (1995a). African-American teachers in the south, 1890-1940: Powerlessness and the ironies of expectations and protest. History of Education Quarterly, 35(4), 401-422.

Fultz, M. (1995b). African-American teachers in the south, 1890-1940: Growth, feminization, and salary discrimination. Teachers College Record, 96(3), 544-568.

Fultz, M. (1996). Teacher training and African American education in the south, 1900-1940. Journal of Negro Education, 64(2), 196-201.

Gallin, A. (2000). Negotiating identity: Catholic higher education since 1960. Notre Dame, IN: University of Notre Dame Press.

Geiger, R. (1986). To advance knowledge: The growth of American research universities. New York: Oxford University Press.

Geiger, R. (1993). Research and relevant knowledge: American research universities since World War II. New York: Oxford University Press.

Geiger, R. (Ed.). (2000). The American college in the nineteenth century. Nashville: Vanderbilt University Press.

Gonzalez, G. (1990). Chicano education in the era of segregation. Philadelphia: The Balch Institute Press.

Gordon, L. (1990). Gender and higher education in the progressive era. New Haven: Yale University Press.
Graham, H. D., \& Diamond, N. (1997). The rise of American research universities: Elites, and challengers in the postwar era. Baltimore: Johns Hopkins University Press.

Greer, C. (1972). The great school legend: A revisionist interpretation of American public education. New York: Basic Books.

Griffin, G. B. (1984). Women's education in the midwest: Emancipated spirits. Change, 16(1), 32-40.

Grubb, W. N., \& Lazerson, M. (1982). Broken promises: How Americans fail their children. New York: Basic Books.

Harlan, L. R. (1983). Booker T. Washington: The wizard of Tuskegee, 1901-1915. New York: Oxford University Press.

Hershberg, J. (1993). James B. Conant: Harvard to Hiroshima and the making of the nuclear age. New York: Knopf

Hoffman, N. (1981). Woman's "true" profession: Voices from the history of teaching. New York: McGraw Hill.

Hofstadter, R. (1961). Academic freedom in the age of the college. New York: Columbia University Press.

Hofstadter, R., \& Metzger, W. (1955). The development of academic freedom in the United States. New York: Columbia University Press.

Horowitz, H. L. (1984). Alma mater: Design and experience in the women's colleges from their nineteenth century beginnings to the 1930s. Amherst: University of Massachusetts Press.

Horowitz, H. L. (1987). Campus life: Undergraduate cultures from the end of the eighteenth century to the present. New York: Knopf.

Horowitz, H. L. (1994). The power and passion of M. Carey Thomas. New York: Knopf.

Hutcheson, P. (1999). Reconsidering the community college. History of Education Quarterly. 39(3), 307-320.

Johanek, M. (Ed.). (in press). A faithful mirror: Reflections on the College Board and education in America. New York: College Entrance Examination Board.

Johnson, W. (1974). Education and professional lifestyles: Law and medicine in the nineteenth century. History of Education Quarterly, 14(2), 185-207.

Kaestle, C. F. (1973). The evolution of an urban school system: New York City, 1750-1850. Cambridge: Harvard University Press.

Kaestle, C. F., \& Vinovskis, M. (1980). Education and social change in nineteenth-century Massachtisetts. New York: Cambridge University Press.

Kantor, H. (1988). Learning to earn: School, work, and wocational reform in California, 1880-1930. Madison: University of Wisconsin Press.

Karier, C. J. (1975). Shaping the American educational state, 1900 to the present. New York: Free Press.

Karier, C., Violas, P, \& Spring, J. (1973). Roots of crisis: American education in the twentieth century. Chicago: Rand McNally.

Katz, M. (1968). The irony of early school reform: Educational innovation in mid-nineteenth century Massachusetts. Boston: Beacon Press.

Katz, M. (1971). Class, bureaucracy, and schools: The illusion of educational change in America. New York: Praeger.

Katz, M. (1983). Poverty and policy in American history. New York: Academic Press.

Katz, M. (1986). In the shadow of the poorhouse: A social history of welfare in America. New York: Basic Books.

Katz, M. (1987). Restructuring American education. Cambridge: Harvard University Press.

Kimball, B. A. (1992). The "true professional ideal" in America: A history. Cambridge, U.K.: Blackwell.

Kirst, M. W. (1984). Who controls our schools? America's values in conflict. New York: W.H. Freeman and Company.

Kozol, J. (1967). Death at an early age: The destruction of the hearts and minds of Negro children in the Boston public schools. Boston: Houghton Mifflin.

Labaree, D. (1988). The making of an American high school: The credentials market and the Central High of Philadelphia, 1838-1939. New Haven: Yale University Press.

Labaree, D. (1997). How to succeed in school without really learning: The credentials race in American education. New Haven: Yale University Press.

Lagemann, E. C. (1979). A generation of women: Education in the lives of progressive reformers. Cambridge: Harvard University Press.

Lagemann, E. C. (1989). The politics of knowledge: The Carnegie Corporation, philanthropy. and public policy. Middletown, CT: Wesleyan University Press.

Lagemann, E. C. (Ed.). (1999). Philanthropic foundations: New scholarship, new possibilities. Bloomington, IN: Indiana University Press. 
Lagemann, E. C. (2000). An elusive science: The troubling history of education research. Chicago: University of Chicago Press.

Lagemann, E. C., \& Shulman, L. S. (1999). Issues in education research: Problems and possibilities. San Francisco: Jossey-Bass Publishers.

Lasser, C. (Ed.). (1987). Educating men and women together: Coeducation in a changing world. Urbana, IL: University of Illinois Press.

Lazerson, M. (1971). Origins of the urban school: Public education in Massachusetts, 1870-1915. Cambridge, MA: Harvard University Press.

Lazerson, M. (1973). Revisionism and American educational history. Harvard Educational Review, 43(2), 269-283.

Lazerson, M. (1987). American education in the twentieth century: $A$ documentary history. New York: Teachers College Press.

Lazerson, M. (1998). Whither America's fellowships. Change, 30(May/ June), pp. 27-33.

Lazerson, M., \& Grubb, W. N. (1974). American education and vocationalism: A documentary history, 1870-1970. New York: Teachers College Press.

Leloudis, J. L. (1996). Schooling the new south: Pedagogy, self, and society in North Carolina, 1880-1920. Chapel Hill: University of North Carolina Press.

Lemann, N. (1999). The big test: The secret history of the American meritocracy. New York: Farrar, Straus, and Giroux.

Levin, B. (1994). Educating elementary school teachers: The struggle for coherent visions, 1909-1978. Lanham, MD: University Press of America.

Levine, D. O. (1986). The American college and the culture of aspiration, 1915-1940. Ithaca: Cornell University Press.

Levine, L. W. (1996). The opening of the American mind: Canons, culture, and history. Boston: Beacon Press.

Link, W. A. (1995). William Friday: Power, purpose, and American higher education. Chapel Hill: University of North Carolina Press.

Ludmerer, K. M. (1985). Learning to heal: The development of American medical education. New York: Basic Books.

Ludmerer, K. M. (1999). Time to heal: American medical education from the turn of the century to the era of managed care. New York: Oxford University Press.

Mahoney, K. A. (in press). Catholic higher education in Protestant America: The Jesuits and Harvard in the age of the university, 1893-1910. Baltimore: Johns Hopkins University Press.

Marsden, G. M. (1994). The soul of the American university: From Protestant establishment to established nonbelief. New York: Oxford University Press.

Mayer, M. S. (1993). Robert Maynard Hutchins: A memoir. Berkeley: University of California Press.

Metzger, W. (1961). Academic freedom in the age of the university. New York: Columbia University Press.

Nerad, M. (1999). The academic kitchen: A social history of gender stratification at the Unizersity of California, Berkeley. Albany: State University of New York Press.

Nidiffer, J. (2000). Pioneering deans of women: More than wise and pious matrons. New York: Teachers College Press.

Noble, D. F. (1977). America by design: Science, technology, and the rise of corporate capitalism. New York: Knopf

Palmieri, P. A. (1995). In Adamless Eden: The community of women faculty at Wellesley. New Haven: Yale University Press.

Perkins, L. M. (1987). Fanny Jackson Coppin and the Institute for Colored Youth, 1837-1902. New York: Garland Publishing.

Perkins, L. M. (1993). The role of education in the development of black feminist thought, 1860-1920. History of Education Quarterly, 22(3), 265-275.

Perkinson, H. (1968). The imperfect panacea: American faith in education, 1865-1965. New York: Random House.

Potts, D. B. (1992). Wesleyan University, 1831-1910: Collegiate enterprise in New England. New Haven: Yale University Press.

Powers, J. B. (1992). The "girl question" in education: Vocational education for young women in the Progressive Era. New York: Falmer Press.

Prentice A., \& Theobald, M. (Ed.). (1991). Women who taught: Perspectives on the history of women and teaching. Toronto: University of Toronto Press.

Raftery, J. R. (1992). Land of fair promise: Politics and reform in Los Angeles schools, 1885-1941. Stanford, CA: Stanford University Press.

Ravitch, D. (1977). The revisionists revised: A critique of the radical attack on schools. New York: Basic Books.

Ravitch, D. (1995). Debating the future of American education: Do we need national standards and assessments? Washington, DC: The Brookings Institution.
Ravitch, D. (2000). Left back: A century of failed school reform. New York: Simon and Schuster.

Ravitch, D., \& Vinovskis, M. (1995). Learning from the past: What history teaches us about school reform. Baltimore: Johns Hopkins University Press.

Reese, W. J. (1995). The origins of the American high school. New Haven: Yale University Press.

Reuben, J. (1996). The making of the modern university: Intellectual transformation and marginalization of morality. Chicago, University of Chicago Press.

Reuben, J. (in press). Merit, mission, and minority students: The history of debates over special admissions programs. In M. Johanek (Ed.), A faithful mirror: Reflections on the College Board and education in America. New York: College Board.

Ritterband, P., \& Wechsler, H. S. (1994). Jewish learning in American universities: The first century. Bloomington, IN: Indiana University Press.

Rosenberg, R. (1982). Beyond separate spheres: Intellectual roots of modern feminism. New Haven: Yale University Press.

Rossiter, M. W. (1982). Women scientists in America: Struggles and strategies to 1940. Baltimore: Johns Hopkins University Press.

Rossiter, M. W. (1995). Women scientists in America: Before affirmative action, 1940-1972. Baltimore: Johns Hopkins University Press.

Rousmaniere, K. (1997). City teachers: Teaching and school reform in historical perspective. New York: Teachers College Press.

Rudolph, F. (1962). The American college, a history. New York: Knopf.

Rury, J. (1991). Education and women's work: Female schooling and the division of labor in urban America, 1870-1930. Albany: State University of New York Press.

San Miguel, G. (1987). "Let all of them take heed," Mexican Americans and the campaign for educational equality in Texas, 1910-1981. Austin: Uni*ersity of Texas Press.

Seflossman, S. L., \& Sedlak M. (1988). The age of reform in American management education. Los Angeles: Graduate Management Admission Council.

Schlossman, S., Sedlak M., \& Wechsler, H. (1998). The "new look": The Ford Foundation and the revolution in business education. Selections, 14(3), 8-28.

Soloman, B. M. (1985). In the company of women: $A$ history of women and higher education in America. New Haven: Yale University Press.

Spring, J. (1976). The sorting machine: National educational policy since 1945. New York: McKay.

Synnott, M. G. (1979). The half-opened door: Discrimination and admissions at Harvard, Yale, and Princeton, 1900-1970. Westport, CT: Greenwood Press.

Tyack, D. (1974). The one best system: A history of American urban education. Cambridge: Harvard University Press.

Tyack, D. (1976). Ways of seeing: An essay on the history of compulsory schooling. Harvard Educational Review, 46(3), 355-389.

Tyack, D., \& Cuban, L. (1995). Tinkering tou'ard utopia: A century of public school reform. Cambridge: Harvard University Press.

Tyack, D., \& Hansot, E. (1990). Learning together: A history of coeducation in American public schools. New Haven: Yale University Press.

Veysey, L. R. (1965). The emergence of the American university. Chicago: University of Chicago Press.

Vinovskis, M. (1985). The origins of public high schools: A recxamination of the Beverly High School controversy. Madison: University of Wisconsin Press.

Vinovskis, M. (1999). History and educational policymaking. New Haven: Yale University Press.

Walker, V. S. (1996). Their highest potential: An African American school community in the segregated south. Chapel Hill: University of North Carolina Press.

Warren, D. (Ed.). (1989). American teachers: Histories of a profession at work. New York: Macmillan.

Wechsler, H. S. (1977). The qualified student: A history of selective college admission in America. New York: Wiley.

Weiler, K. (1998). Country schoolwomen: Teaching in rural California, 1850-1950. Stanford, CA: Stanford University Press.

Manuscript received August 15, 2000

Revision received September 7, 2000

Accepted September 10, 2000 